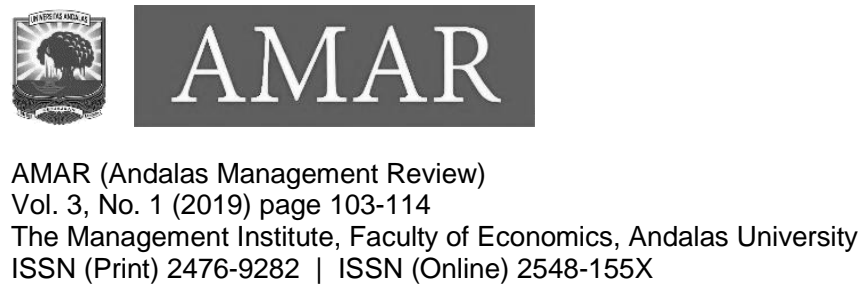

\title{
SME Internal Capability and Competitive Advantage in an Emerging Market: Moderating Effects of Firm Age
}

\author{
Donard Games, Roliza \\ Department of Management, Faculty of Economics, Universitas Andalas \\ donardgames@eb.unand.ac.id
}

\begin{abstract}
This study aims to determine the effect of small business internal capabilities on competitive advantage in which firm age was expected to moderate the relationship between these two constructs. The present study also considers the context of Indonesia as an emerging market economy as an important characteristic that can provide some additional perspectives related to SME competitive advantage. Here competitive advantage come from the resource-based view theory which sees SME capabilities will shape their competitiveness. The present study uses quantitative approach, using SmartPLS, by surveying 52 food SMEs in Padang, West Sumatra, Indonesia. It was found that SME internal capability was positively and significantly related to competitive advantage. Additionally, firm age moderated the relationship between SME internal capability and competitive advantage in young SME group (SMEs with the firm age less than 5 years), while this was not the case for old SME group (SMEs with the age more than 5 years). In an emerging market such as Indonesia, this may represent the urgency to consistently strengthen SME internal capability.

Keyword: SME internal capability, SME Innovation, competitive advantage, firm age, emerging market
\end{abstract}

\section{INTRODUCTION}

While competitive advantage can give significant benefits to business organizations, small and medium enterprises (SMEs) may have difficulties in terms of internal capabilities. SMEs may need to deal with insufficient internal funds, inadequate managerial skills, lack of job skills, and lack of access to markets (Dada \& Fogg, 2014). Therefore, if they have strong internal capabilities, it is more likely for them to be able to compete. This conceptualization is supported by the theory of Resource-Based View (henceforth RBV), presented by Barney (1991), which states that competitive advantage has a strong link with strategic choice, in particular, assigning company managers with the important task of identifying, developing, and using key resources 
to maximize results. In brief, if SMEs are able to use and develop the resources they have well, then they will get maximum results and their own advantages in dealing with competition.

According to Williams and Hare (2012), the main reason why SMEs need to gain competitive advantage is that it can enhance their ability to develop unique products and their flexibility in adopting new technologies. For this reason, SMEs need to pay attention to human resources skills and investment for increasing skills which are considered as internal capabilities in order to gain competitive advantage (Avermaete, Viaene, Morgan, \& Crawford, 2003) especially in an intense market competition. Indonesia as an emerging market with an intense competition may offer both business opportunities and challenges. The present study examines food SME internal capabilities and competitive advantage. Food SMEs is a growing business in Indonesia at this time. The emergence of a variety of unique foods, the presence of culinary tourism, and culinary trends as people's lifestyles, may indicate that this business is growing rapidly. However, this sector is known for its high turnover. It is also relatively easy to enter and exit this sector, so that there must be an intense competition. Therefore, SME must have a competitive advantage in order to continue to survive and develop amid an intense competition.

According to Ismail (2013), the importance of SMEs in economic growth and their ability to provide employment opportunities has made researchers learn about key success factors of SMEs to gain competitive advantage. Although this research leads to knowledge of innovations and competitive advantages of SMEs, more recent research shows that younger companies are more likely to innovate, thus providing more benefits to the competitiveness of the company (Higon, 2011). In contrast, Harris, Rogers and Siouclis (2003), and Zhang (2006), states that there is no significant influence of firm age on the relationship of innovation and competitive advantage. This shows that there are different findings on the impact of firm age on the link between SME innovation and competitive advantage. The present study wants to confirm this situation from the context of Indonesia as an emerging market economy.

Larsen and Lewis (2007) argue that the essence of character of entrepreneurs is their ability to innovate. Without innovation the company will not last long. For this reason, there is a need for continuous improvement if the company will continue further and remain standing with its efforts. According to Avermaete et.al. (2003), business organizations need to strengthen their 
internal capabilities, more specifically workforce and managerial skills. They have identified that in this regard, internal capabilities have become the key factors that can provide competitive advantage. The RBV theory views the company as a collection of resources and capabilities owned by the company. Differences in resources and the ability of companies compared to competing companies will provide competitive advantages for the company (Barney, 1991). The RBV perceives that resources must meet the criteria of "VRIO" (Valuable, Rare, difficult to imitate resources (imperfect imitable), and Organizational support).

Higon (2011) and Avermaete et.al. (2003) identified that younger companies are more likely to innovate, thus providing more benefits to the competitiveness of the company. These researcher states that young companies behave more proactively, flexibly and aggressively. Some other studies stated that there is no significant influence of the firm age on the relationship of SME internal capability and competitive advantage (Harris et al, 2003), but as suggested by Aziz and Samad (2016), young SME group may have different characteristics in terms of business innovation and innovation capabilities. This may strengthen a notion that firm age may moderate the link between SME internal capability and competitive advantage.

In brief, based on the explanations above, hypotheses can be postulated as follows:

H1: SME internal capability is positively related to competitive advantage

H2: Firm age moderates the relationship between SME internal capability and competitive advantage

\section{RESEARCH METHODOLOGY}

As can be seen from the figure 1 below, the present study examines the relationship between SME internal capabilities and competitive advantage and to see whether firm age moderates the relationship between these two constructs. The present study uses quantitative approach by conducting a survey of 52 food SME owners/managers in Padang, West Sumatra. By using simple random sampling, the respondents were taken from local government document. Data is analyzed using the SmartPLS 3. 


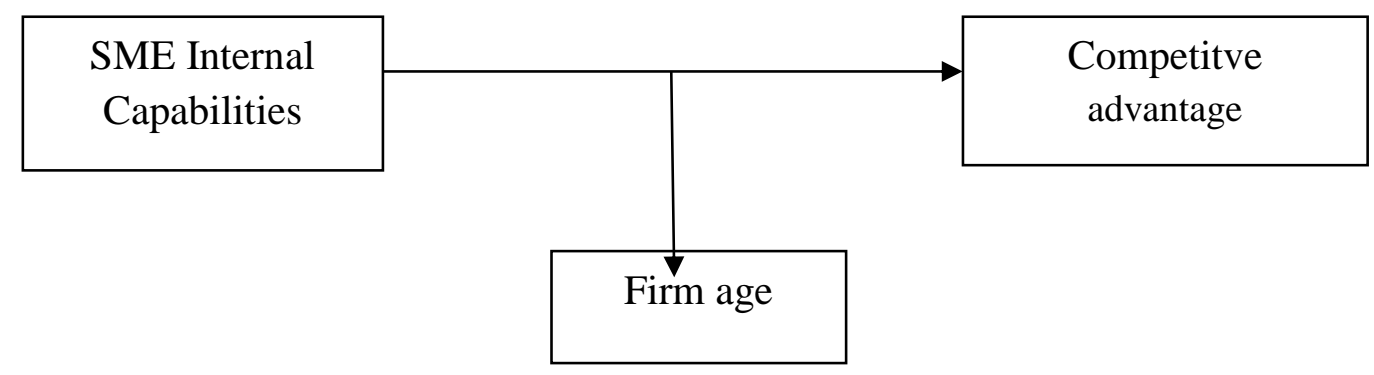

Figure 1. Research model

As can be seen from table 1, SME internal capabilities were measured using items adapted from Avermaete et al. (2003) which were also adopted by Aziz and Samad (2016). SME internal capabilities measure was used by asking whether in the respondent's SMEs: "managerial staff skills are important"; "employees skills are important"; training is important; marketing aspect are important; and lastly, "An ability to absorb information from external informant". In terms of competitive advantage, the present study uses VRIO from Barney (1991): Valuable, Rare, Inimitability, and Organizational support. In this case, competitive advantage was measured using items adapted from Kim, Lee, and Shin (2015). Competitive advantage measure was used by asking whether in the respondent's SMEs: Value (improvement in business performance; increase in profit; responses to environmental threats and opportunities; improvement in reputation), Rare (uniqueness, used by small number of firms), Inimitability (difficulty to imitate due to firm's historical nature; difficulty to imitate due to the difference in organizational culture; difficulty to imitate due to technology), and lastly, Organizational support (management support; reward system; and organizational structure). The present study uses a 5 point Likert Scale ( $1=$ strongly disagree and $5=$ strongly agree). 52 questionnaires have been distributed, and all of them that could be further analyzed. Of the 52 respondents there were 30 men and 20 women predominantly aged between 36 and 45 . More importantly, in terms of firm age, 29 of the SMEs aged less than 5 years, while 23 aged more than 5 years. 


\section{Table 1}

Measurement

\begin{tabular}{|c|c|c|c|c|}
\hline Construct & Definition & Indicators & Scale & Sources \\
\hline $\begin{array}{l}\text { Internal } \\
\text { capability }\end{array}$ & $\begin{array}{l}\text { skills and } \\
\text { investment for } \\
\text { increasing skills } \\
\text { which are } \\
\text { considered as } \\
\text { internal } \\
\text { capabilities in } \\
\text { order to gain } \\
\text { competitive } \\
\text { advantage }\end{array}$ & $\begin{array}{l}\text { Managerial skills } \\
\text { ("managerial } \\
\text { staff skills are } \\
\text { important"; } \\
\text { "employees } \\
\text { skills are } \\
\text { important"; } \\
\text { training is } \\
\text { important; } \\
\text { marketing aspect } \\
\text { are important; } \\
\text { and lastly, } \\
\text { "An ability to } \\
\text { absorb } \\
\text { information } \\
\text { from external } \\
\text { informant" }\end{array}$ & $\begin{array}{l}\text { 5point Likert } \\
\text { Scale }(1= \\
\text { strongly } \\
\text { disagree and } \\
5=\text { strongly } \\
\text { agree) }\end{array}$ & $\begin{array}{l}\text { Avermaete et } \\
\text { al., 2003) }\end{array}$ \\
\hline $\begin{array}{l}\text { Competitive } \\
\text { advantage }\end{array}$ & $\begin{array}{l}\text { Non-duplicable } \\
\text { advantages by } \\
\text { the effort of } \\
\text { competitors } \\
\text { (Barney, 1991) }\end{array}$ & $\begin{array}{l}\text { Value } \\
\text { (improvement in } \\
\text { business } \\
\text { performance; } \\
\text { increase in } \\
\text { profit; responses } \\
\text { to } \\
\text { environmental } \\
\text { threats and } \\
\text { opportunities; } \\
\text { improvement in } \\
\text { reputation), } \\
\text { Rare } \\
\text { (uniqueness, } \\
\text { used by small } \\
\text { number of } \\
\text { firms), } \\
\text { Inimitability } \\
\text { (difficulty to } \\
\text { imitate due to } \\
\text { firm's historical } \\
\text { nature; difficulty } \\
\text { to imitate due to } \\
\text { thedifference in }\end{array}$ & $\begin{array}{l}\text { 5point Likert } \\
\text { Scale }(1= \\
\text { strongly } \\
\text { disagree and } \\
5=\text { strongly } \\
\text { agree) }\end{array}$ & $\begin{array}{l}\text { Kim, Lee, \& } \\
\text { Shin, 2015) }\end{array}$ \\
\hline
\end{tabular}




\begin{tabular}{|c|c|c|c|c|}
\hline Construct & Definition & Indicators & Scale & Sources \\
\hline & & $\begin{array}{l}\text { organizational } \\
\text { culture; } \\
\text { difficulty to } \\
\text { imitate due to } \\
\text { technology), and } \\
\text { lastly, } \\
\text { Organizational } \\
\text { support } \\
\text { (management } \\
\text { support; reward } \\
\text { system; and } \\
\text { organizational } \\
\text { structure). }\end{array}$ & & \\
\hline \multirow[t]{2}{*}{ Firm age } & $\begin{array}{l}\text { the number of } \\
\text { years of } \\
\text { incorporation of } \\
\text { the company }\end{array}$ & $\begin{array}{l}\text { young SME } \\
\text { group }\end{array}$ & $\begin{array}{l}\text { (less than } 5 \\
\text { years) }\end{array}$ & $\begin{array}{l}\text { Aziz \& Samad } \\
\text { (2016) }\end{array}$ \\
\hline & & old SME group & $\begin{array}{l}\text { (more than } 5 \\
\text { years }\end{array}$ & \\
\hline
\end{tabular}

Source: Measurement (2018)

\section{RESULTS}

\subsection{Validity and Reliability}

In terms of discriminant validity, an examination of the correlations between the constructs, shown in Table 2 suggested that there is no problem as each construct was not highly correlated each other. All of the multiple-item constructs had acceptable measurement properties and the models that were outlined previously could be estimated with confidence. Convergent validity also can be assumed as the AVE score ranged from 0.77 to 0.56 . The composite reliability coefficients ranged from 0.679 to 0.990 , so that reliability could be assumed. 
Andalas Management Review, Vol. 3 No. 1, 2019

Table 2

The correlations between the constructs

\begin{tabular}{|c|c|c|c|c|c|c|c|}
\hline & I & IC & CA & ORG & $\mathbf{R R}$ & FA & V \\
\hline I & 1.000 & & & & & & \\
\hline IC & 0.383 & 1.000 & & & & & \\
\hline CA & 0.826 & 0.526 & 1.000 & & & & \\
\hline ORG & 0.326 & 0.385 & 0.694 & 1.000 & & & \\
\hline $\mathbf{R R}$ & 0.685 & 0.441 & 0.804 & 0.301 & 1.000 & & \\
\hline FA & 0.049 & 0.123 & 0.189 & 0.293 & 0.080 & 1.000 & \\
\hline V & 0.344 & 0.371 & 0.646 & 0.372 & 0.444 & 0.139 & 1.000 \\
\hline
\end{tabular}

Source: Data is processed (2018)

\subsection{Structural Model}

Table 3

Path Coefficients

\begin{tabular}{ccccc}
\hline & $\begin{array}{c}\text { Original } \\
\text { Sample } \\
(\mathbf{O})\end{array}$ & $\begin{array}{c}\text { Sample Mean } \\
(\mathbf{M})\end{array}$ & $\begin{array}{c}\text { Standard } \\
\text { Deviation } \\
\text { (STDEV) }\end{array}$ & $\begin{array}{c}\text { T Statistics } \\
(\mid \text { O/STERR } \mid)\end{array}$ \\
\hline IC $\rightarrow$ CA & 0,480 & 0,477 & 0,022 & 21,80
\end{tabular}

Source: Data is processed (2018)

Based on the table above, internal capabilities (IC) significantly and positively related to competitive advantage (CA). Furthermore, based on T-values of 21.80 is greater than T-table 1.64 on the confidence interval of $95 \%$ and at the $p$ values $5 \%$. Therefore, it can be concluded that the first hypothesis is supported. 


\subsection{Moderating Effect}

Table 4

Path Coefficients-Young SME group

\begin{tabular}{cccccc}
\hline & $\begin{array}{c}\text { Original } \\
\text { Sample } \\
(\mathbf{O})\end{array}$ & $\begin{array}{c}\text { Sample } \\
\text { Mean } \\
(\mathbf{M})\end{array}$ & $\begin{array}{c}\text { Standard } \\
\text { Deviation } \\
(\text { STDEV) }\end{array}$ & $\begin{array}{c}\text { Standard } \\
\text { Error } \\
(\text { STERR) }\end{array}$ & $\begin{array}{c}\text { T Statistics } \\
(\mid \text { O/STERR } \mid)\end{array}$ \\
\hline $\begin{array}{c}\text { IC -> } \\
\text { FA }\end{array}$ & $-0,123$ & $-0,119$ & 0,024 & 0,024 & 5,116 \\
\hline $\begin{array}{c}\text { IC * FA } \\
->\text { CA }\end{array}$ & 0,405 & 0,376 & 0,167 & 0,167 & 2,428 \\
\hline $\begin{array}{c}\text { FA -> } \\
\text { CA }\end{array}$ & $-0,146$ & $-0,120$ & 0,173 & 0,173 & 0,843 \\
\hline
\end{tabular}

Source: Data is processed (2018)

Table 5

Path Coefficients-Old SME grup

\begin{tabular}{cccccc}
\hline & $\begin{array}{c}\text { Original } \\
\text { Sample } \\
(\mathbf{O})\end{array}$ & $\begin{array}{c}\text { Sample } \\
\text { Mean } \\
\mathbf{( M )}\end{array}$ & $\begin{array}{c}\text { Standard } \\
\text { Deviation } \\
\mathbf{( S T D E V )}\end{array}$ & $\begin{array}{c}\text { Standard } \\
\text { Error } \\
(\text { STERR })\end{array}$ & $\begin{array}{c}\text { T Statistics } \\
(\mid \text { O/STERR } \mid)\end{array}$ \\
\hline IC-> FA & $-0,123$ & $-0,133$ & 0,045 & 0,045 & 2,748 \\
\hline $\begin{array}{c}\text { IC * FA - } \\
\text { > CA }\end{array}$ & 0,405 & 0,408 & 0,259 & 0,259 & 1,562 \\
\hline $\begin{array}{c}\text { FA -> } \\
\text { CA }\end{array}$ & $-0,146$ & $-0,142$ & 0,272 & 0,272 & 0,538 \\
\hline
\end{tabular}

Source: Data is processed (2018)

Table 4 and 5 show the relationship between internal capabilities (IC and competitive advantage (CA) in which firm age (FA) as moderator. From table 4 can be seen that SME internal capability is positively related to competitive advantage with firm age as moderator as the Tvalues (2.428) is greater than T-table (1.64) at $\mathrm{P}$ value 5\%. Therefore, it can be concluded the second hypothesis is supported. In brief, firm age moderated the relationship between SME internal capability and competitive advantage. In this case, young SME group (SMEs with firm age less 
than 5 years) significantly and positively influences the effect of SME internal capability on competitive advantage. Additionally, table 4 shows that the T-values (1.562) is smaller than T table. Therefore, old SME group did not moderate the relationship between SME internal capability and competitive advantage.

\section{DISCUSSION}

RBV essentially can be seen as the effective and efficient application of all useful resources that the firm can use in order to achieve competitive advantage (Barney, 1991). In this regard, SME internal capabilities can be seen as a way to maximize the potential of SME resources especially by enhancing human resources skills within organization in order to able to compete. This is harder difficult for SMEs that have difficulties in exploiting their limited resources. It is not easy, for example, to be unique and inimitable as these are required in resource-based view, as they may be costly. Human resources skills and investment for training, for example, may not instantaneously help SME financial performance. Here resource-based view emphasized the importance of SME internal capability as a way to enhance competitive advantage.

The present study found that SME internal capability is positively related to competitive advantage. This is in line with previous studies that found that SME internal capability that includes workforce skills, managerial skills, investment in training, and an ability to interpret market knowledge as important key factors that lead to highly competitive advantage SMEs (e.g. Avermaete et al., 2003; Aziz \& Samad, 2016; William \& Hare, 2012). This finding may also be used for food SMEs to establish networks with external actors such as universities and government. Food SMEs may not have capabilities to develop new products by themselves. They may not have strong R\&D to successfully be able to compete. They need, for example, universities as the centre for innovation that can provide unique characteristics that distinguish these SME products compared to their existing competitors.

In terms of firm age as moderator, it was found that firm age did moderate the relationship between SME internal capabilities and competitive advantage. More specifically young SME group (less than 5 years) positively and significantly influences the effect of SME internal capabilities on competitive advantage, while old SME group (SMEs with firm age more than 5 years) did not moderate the relationship between SME internal capability and competitive advantage. This is in line with previous studies that found that younger companies are more likely to make changes, 
thus providing more benefits to the competitiveness of the company (Aziz \& Samad, 2016; Higon, 2011). They are relatively independent and open minded, so that they can benefit from external assistances. This finding is not in line with previous studies that found that firm age has no link with the relationship between SME internal capabilities and competitive advantage (e.g. Harris et al., 2003; Zhang, 2006).

The present study uses the context of Indonesia as an emerging market economy. Its most important characteristic is a market that offers both business opportunities and business challenges. SME internal capability that includes comprehensive approach in enhancing human resources within SMEs in an emerging market economy such as Indonesia may be costly, but it is worth doing as it can give monetary benefit as well as better organizational performance in the future (Games, 2019). Food SMEs may have been dealing a greater challenge as it is highly competitive, but this should not inhibit them to invest on human resources skills even if they have been running their businesses more than five years. Internal capabilities require continuous improvement that needs courage and resilience. Without that, these SME will not survive in an intense competition.

\section{CONCLUSION}

SME internal capability is positively and significantly related to competitive advantage. From the lens of resource-based view, this may signify the importance of human resource skills and investment for human resources within organization in order to maximize the SME resources. In turn, this will enhance SME competitiveness. It was also found that young SME group moderates the link between SME internal capability and competitive advantage. This means that SMEs with less than 5 years may be more likely to increase their skills and benefit from their investment in human resources which will result in a better level of competitive advantage. The context of Indonesia as an emerging market economy offer both opportunities and business challenges. This may encourage SMEs to focus on SME internal capability even if it is costly.

\section{IMPLICATIONS}

Food SMEs may have been dealing with a greater difficulty in terms of competition. For this reason, they need to consistently strengthen their internal capabilities. Internal capabilities emphasize the importance of workforce and managerial skill and investment in training as well as 
absorption of external knowledge. Top management team or founder in SMEs need to invest on these things. Food SMEs, in the present study, considerably focuses on product innovation, but they may not have resources especially knowledge in implementing innovation. They may need to come to see innovators from universities to enhance their level of innovation. SMEs with firm age less than 5 years need to strengthen their position in these years as it may be the most important moment to focus on SME internal capability. For SMEs that aged more than 5 years, they need to refresh their motivation and commitment to innovation. This will strengthen their position in an intense market in Indonesia.

The present study has 52 respondents from food SMEs in West Sumatra. Future research can have more respondents from various types of businesses in some provinces in Indonesia. SME internal capability in this study uses workforce and managerial skills, investment in human resources skills, as well as an ability to interpret knowledge from eternal environment. Perhaps future research can use more comprehensive approach by using different types of internal capabilities such as R\&D especially in high-tech SMEs. Another important construct such as SME resiliency and SME innovativeness may provide some more insights from SME internal capability and competitive advantage.

\section{REFERENCES}

Avermaete, T., Viaene, J., Morgan, E. J., \& Crawford, N. (2003). “Determinants of innovation in small food firms.", European Journal of Innovation Management, Vol. 6, No. 1, pp. 8-17.

Aziz, NNA., \& Samad, Sarminah. (2016). "Innovation and Competitive Advantage: Moderating Effects of Firm Age in Foods Manufacturing SMEs in Malaysia.", Procedia Economics and Finance, Vol. 35, pp. $256-266$.

Barney, JB. (1991), "Firm resource and sustained competitive advantage", Journal of Management, Vol. 17, No. 1, pp. 99-120.

Dada, O., \& Fogg, H., (2014), “Organizational learning, entrepreneurial orientation, and the role of university engagement in SMEs.", International Small Business Journal, pp. 1-19.

Games, D. (2019). "Can SME benefit from innovation in an emerging market economy?.", Academy of Entrepreneurship Journal, Vol. 25, No. 1.

Harris, M. N., Rogers, M., \& Siouclis, A., (2003), "Modelling firm innovation using panel probit estimators.", Applied Economics Letters, Vol. 10, No. 11, pp. 683-686. 
Higon, D.A., (2011), “The impact of ICT on innovation activities: Evidence for UK SMEs.", International Small Business Journal, Vol. 30, No. 6, pp. 684-699.

Ismail, M. D., (2013), “Learning orientation and trust in Small and Medium Enterprise (SME) Export Competitive.", Asian Academy of Management Journal, Vol. 18, No. 2, pp. 153-179.

Kim, S. C., Lee, J. S., \& Shin, K. I., (2015), “The impact of project management assets on the VRIO characteristics of PM process for competitive advantage.", International Journal of Productivity and Quality Management, Vol. 15, No. 2, pp.153-168.

Williams, D., Hare, L., \& UWI, M., (2012), “Competitiveness of small hotels in Jamaica: An exploratory analysis.", Journal of Eastern Caribbean Studies, Vol. 37, No.3, pp. 71-96.

Zhang, M., (2006), "Conceptualizing the learning process in SMES: Improving innovation through external orientation.", International Small Business Journal, Vol. 24, No. 3, pp. 299323. 